wawczej, ich rozwój i ewolucję na przestrzeni dziejów. Można szukać odpowiedzi na pytanie - związki polskiej pedagogiki $z$ europejska myślą wychowawczą. A zapoznając $\mathrm{z}$ najważniejszymi przejawami indywidualnego rozwoju poszczególnych myślicieli możemy stworzyć zarys portretu środowiska pedagogów polskich.

Traktując niniejszą recenzję jako głos w dyskusji (do czego zachęcają Redaktorki) nad publikacja, pozwalam sobie na kilka uwag, które naturalnie mają charakter dyskusyjny.

Bowiem skoro już z opisu struktury i założeń Slownika wynika, iż polską pedagogikę tworzyli także przedstawiciele innych dyscyplin, może wskazane byłoby przy następnej edycji zaangażować do współpracy także innych specjalistów, nie tylko pedagogów i historyków. To przysporzyłoby wielu trudności, zwłaszcza natury organizacyjnej, ale być może byłoby z korzyścią dla opracowania.

Druga uwaga dotyczy w pewnym sensie struktury biogramów. Jeśli przyjmujemy, że
Slownik odzwierciedla aktualny stan wiedzy o historii pedagogiki i jej rozwoju, czy nie lepiej byłoby pod każdym biogramem podać źródła wiedzy o pedagogu? To miałoby znaczenie dla następnego wydania, w którym widoczna byłaby aktualizacja wiedzy.

Trzecie spostrzeżenie odnosi się do pominiętego podczas korekty błędu dotyczącego daty urodzenia i ukończenia studiów $\mathbf{M}$. Węglewicza (s. 215 -216). To jednak przy tego typu wydawnictwach jest nie do uniknięcia.

W sumie to zbiorowe dzieło polskiego środowiska naukowego jest cenną inicjatywą świadczącą o jego aktywności w sferze działań na rzecz rozwoju nauk o wychowaniu. Jest także przykładem starań o zachowanie dyscypliny metodologicznej wyrażającej się w konsekwencji wobec przyjętych zalożeń projektu badawczego. To niewątpliwie zawdzięczamy nie tylko autorom biogramów, ale Redakcji Slownika.

\title{
Noty
}

Erfolg. Niedergang. Neuanfang. 100 Jahre Verband Deutscher Sondarschulen - Fachverband für Behinderten - Pädagogik. Im Aftrag des Verbandes herausgegeben von Andreas Möckel mit Beiträgen von Herwig Baier, Elrich Bleidick, Bodo Bröse, Sieglind Ellgar-Rüttgard, Clemens Hillenbrand, Gustav Kanter, Christian Lindmeier, Andreas Möckel, Norbert Myschker, Bruno Prändl, Franz Rumpler, Ditmar Schmetz, Otto Speck, Ursula Stinkes, Norbert Stoellger, Peter Wachtel. Ernst Reinhardt Verlag München - Basel 1998, ss. 602

Z okazji obchodów 100-lecia Niemieckiego Towarzystwa Szkół Specjalnych (Verband Deutscher Sonderschulen) - zawodowej organizacji pedagogów specjalnych ukazała się praca zbiorowa pod powyższym tytułem. Książka jest zarysem historycznym kształtowania się ruchu pedagogicznego począwszy od konferencji dotyczących pracy z idiotami (Die Konferenz für 
Idioten-Heil-Pflege) od 1875 r. do powstania pedagogiki specjalnej na niemieckim gruncie i rozwoju organizacji.

Dwie części pracy ukazują powstanie organizacji i jej rozwój do I wojny światowej; powstanie stowarzyszenia szkól pomocniczych (Der Verband der Hilfsschulen Deutschlands) w okresie Republiki Weimarskiej i III Rzeszy; stowarzyszenie na tle polityki edukacyjnej Republiki Federalnej Niemiec (1948 - 1998); kongresy i konferencje stowarzyszenia, międzyna- rodową współprace; NRD jako państwo bez stowarzyszenia szkół specjalnych itp.

Część III obejmuje 27 załączników w postaci dokumentów, programów, uchwał, apeli charakteryzujących politykę w zakresie szkół specjalnych i rozwoju pedagogiki specjalnej.

Praca może stanowić ważne studium do poznania dziejów najnowszych i współczesnych szkolnictwa niemieckiego.

\section{Educational Research and Higher Education Reform in Eastern and Central Europa. Red. Erich Leitner. Frankfurt a/M., Berlin, Bern, New York, Paris, Wien 1998, ss. 231, fot. 3, tab. 9}

$\mathrm{Z}$ cyklu Studies in Comparative Education jako tom 6 ukazala się publikacja pod powyższym tytułem. Praca napisana przez międzynarodowy zespól autorów wskazuje na zmiany w szkolnictwie wyższym dokonywane w krajach Europy wschodniej i centralnej. Ukazane sq prace w tym zakresie w takich krajach, jak Austria, Republika Czeska, Słowacja, Wegry, Słowenia, Polska, Ukraina, Rosja, Rumunia i Bułgaria.

Poszczególne rozdzialy dotyczą określonego państwa $\mathrm{i}$ napisane są przez rodzimych znawców problemu. Przez Polaków przygotowane są trzy teksty. Ireneusz Białecki pisze na temat: Anatomy of Higher Educational Services in Poland; Elżbieta Wnuk-Lipińska wypowiada się na temat: Academic Staff Facing a Changing University, zaś Ewa Szemborska omawia zagadnienie pt: Changes in the Market of Educational Services in Poland.

\section{Geschichte der Mädchen und Frauenbildung. Red. Elke Kleinau, Claudia Opitz. Tom II. Vom Vormärzis zur Gegenwart. Campus Verlag. Frankfurt, New York 1996, ss. 673}

Pod redakcja Elki Kleinau, z-cy profesora pedagogiki ogólnej na Uniwersytecie w Bielefeld oraz Claudii Opitz, profesora najnowszej historii na Uniwersytecie w Hamburgu ukazał się drugi tom niezwykle interesującej pracy pod wyżej wymienionym tytulem.

Okazuje się, że zainteresowania badawcze historią edukacji kobiet $\mathrm{i}$ ich rolą społeczna, które przeżywają w Polsce swój renesans (dwie międzynarodowe konferencje naukowe 1997 Poznań-Zajączkowo; 1998 Bydgoszcz-Wielonek) obserwowalne sq̨ także w Niemczech. Okazuje się, że 36 Autorek i Autorów przedstawiło swe prace, które złożyły się tylko na prezentowany tom II.

W części I zatytulowanej Edukacja kobiet $i$ ruch demokratyczny w latach 1830-1870 przedstawiono powstanie i rozwój ogródków 